\title{
Erratum to: Impact of opportunistic testing in a systematic cervical cancer screening program: a nationwide registry study
}

\author{
Mette Tranberg ${ }^{1 *}$, Mette Bach Larsen ${ }^{1}$, Ellen M. Mikkelsen², Hans Svanholm ${ }^{3}$ and Berit Andersen ${ }^{1}$
}

Unfortunately, the original version of this article [1] contained an error. In the methods section page 2, lines 5-8 is written "Systematic cervical cancer screening was introduced in the 1960s in some counties and nonsystematically implemented in the rest of the country until nationwide coverage was achieved in 2007 [19]". This should be corrected to "Systematic cervical cancer screening was introduced in the 1960s in some counties and non-systematically implemented in the rest of the country until nationwide coverage was achieved in the late 1990s $[7,19] "$.

Furthermore, another error was detected in the discussion section under the headline "Comparison with other studies". It is written: "A possible reason may the unsystematic implementation of cervical cancer screening, which reached national coverage only in 2007". This should be corrected to "A possible reason may be the unsystematic implementation of cervical cancer screening, which only reached national coverage in the late 1990's".

\footnotetext{
Author details

'Department of Public Health Programs, Randers Regional Hospital, Skovlyvej 1, Randers DK-8930 NØ, Denmark. ${ }^{2}$ Department of Clinical Epidemiology, Aarhus University Hospital, Olof Palmes Allé 43-45, Aarhus N DK-8200, Denmark. ${ }^{3}$ Department of Pathology, Randers Regional Hospital, Skovlyvej 1, Randers DK-8930 NØ, Denmark.
}

Received: 28 July 2015 Accepted: 14 August 2015 Published online: 14 September 2015

\section{Reference}

1. Tranberg M, Larsen MB, Mikkelsen EM, Svanholm H, Andersen B. Impact of opportunistic testing in a systematic cervical cancer screening program: a nationwide registry study. BMC Public Health. 2015;15:681.

\footnotetext{
* Correspondence: mettrani@rm.dk

'Department of Public Health Programs, Randers Regional Hospital, Skovlyvej 1, Randers DK-8930 NØ, Denmark

Full list of author information is available at the end of the article
}

\section{Submit your next manuscript to BioMed Central and take full advantage of:}

- Convenient online submission

- Thorough peer review

- No space constraints or color figure charges

- Immediate publication on acceptance

- Inclusion in PubMed, CAS, Scopus and Google Scholar

- Research which is freely available for redistribution

Submit your manuscript at www.biomedcentral.com/submit 